Non-ruminants

\title{
Effect of different levels of total dietary fiber on the performance of sows in gestation and lactation
}

\author{
Carlos Alexandre Oelke ${ }^{1^{*}}$ (iD, Andréa Machado Leal Ribeiro², Mirela Noro1, Mari Lourdes \\ Bernardi $^{2}$, Cristiane Casagrande Denardin ${ }^{3}$, Paula Raymundo Nunes ${ }^{1}$, Fernando Cézar Veit ${ }^{1}$, \\ João Carlos Winckler ${ }^{1}$
}

\footnotetext{
${ }^{1}$ Universidade Federal do Pampa, Departamento de Medicina Veterinária, Uruguaiana, RS, Brasil.

${ }^{2}$ Universidade Federal do Rio Grande do Sul, Faculdade de Agronomia, Departamento de Zootecnia, Porto Alegre, RS, Brasil.

${ }^{3}$ Universidade Federal do Pampa, Departamento de Farmácia, Uruguaiana, RS, Brasil.
}

\begin{abstract}
The present study evaluated the effect of variation in the amount of total dietary fiber (TDF) in sow diets, provided from 74 to 114 days of gestation, on the digestibility of nutrients and energy during gestation, as well as productivity and metabolism during gestation and lactation. Thirty-three sows were used in a randomized experimental design. The amounts of TDF in three treatment diets were 156,223 , and $282 \mathrm{~g} \mathrm{~kg}^{-1}$. The daily intake of nutrients and energy was similar for all diets the entire period of gestation, differing only in the volume of ration consumed, which was 2.1, 2.2, and $2.4 \mathrm{~kg}$ day ${ }^{-1}$ (days 74 to 90 ) and $2.5,2.6$, and $2.8 \mathrm{~kg} \mathrm{day}^{-1}$ (days 91 to 111 ) for the 156,223 , and $282 \mathrm{~g} \mathrm{~kg}^{-1} \mathrm{TDF}$ diets, respectively. During gestation, the increase in TDF resulted in a significant linear decrease in the digestible energy and apparent total tract digestibility of dry matter, gross energy, crude protein, non-fibrous carbohydrates, and organic matter. During gestation, blood concentrations of protein and globulins exhibited a quadratic response to the amount of TDF in the diet, whereas cholesterol exhibited a significant linear increase. The productivity and reproductive performance of the sows during gestation and lactation or the birth weight of the piglets were not affected by the amount of TDF, but the average daily weight gain of the litter during nursing increased linearly with increasing levels of dietary fiber. Increasing the amount of TDF reduces the digestibility of nutrients and energy, without affecting the performance of the sows during gestation and lactation or that of the piglets at birth and increasing TDF during gestation improves the weight gain of piglets during lactation.
\end{abstract}

Key Words: digestibility, insulin, piglets

\section{Introduction}

The addition of fiber to the diet of sows helps to control weight and minimize the stress associated with confinement in gestation crates and feed restrictions that pregnant females endure (Ramonet et al., 1999; Danielsen and Vestergaard, 2001; Gentilini et al., 2003). This improves the productivity of sows, since the excess energy intake during gestation impairs the formation of the mammary glands and leads to lower milk production during lactation, as well as impacts negatively the feed intake during lactation (Weldon et al., 1991). Compared with diets that contain 33 and $106 \mathrm{~g} \mathrm{~kg}^{-1}$ crude fiber, a diet with $181 \mathrm{~g} \mathrm{~kg}^{-1}$ of crude

Received: November 28, 2017

Accepted: February 20, 2018

*Corresponding author: carlosalexandreoelke@gmail.com

Copyright (C) 2018 Sociedade Brasileira de Zootecnia. This is an Open Access article distributed under the terms of the Creative Commons Attribution License (http://creativecommons.org/licenses/by/4.0/), which permits unrestricted use, distribution, and reproduction in any medium, provided the original work is properly cited. fiber improves welfare by prolonging the post-prandial satiety feeling after feeding (Ramonet et al., 1999).

In addition to improving sow welfare, the addition of fiber to sow diets during gestation might positively affect the birth weight of piglets and feed intake of sows during lactation (van der Peet-Schwering et al., 2003; Veum et al., 2009). Despite the substantial debate over the use of fiber in the diet of pregnant sows, there remain uncertainties over its use (Reese et al., 2008), mainly in relation to the level of total dietary fiber (TDF) to be used. According to NRC (2012), the main challenge in measuring TDF is its implementation in nutrition laboratories. In addition, it is important to evaluate the effect of TDF and its soluble and insoluble fractions on animal metabolism, as well as on the satiety and performance of gestating sows.

This study evaluated the effect of variation in the amount of TDF in the diet, from 74 to 114 days of gestation, on nutrient digestibility, productivity, and metabolism of sows during both gestation and lactation. We hypothesized that the increase in fiber intake during gestation would increase the birth weight and reduce the number of stillborn 
piglets. Furthermore, the use of dietary fiber during gestation may increase the voluntary feed intake of sows during lactation, thus improving the weight gain of piglets during nursing.

\section{Material and Methods}

Research on animals was conducted according to the institutional committee on animal use (case number 006/20014). The present study was conducted in Itaqui, Rio Grande do Sul - Brazil (Latitude: 2907'31" South, Longitude: 56 $33^{\circ} 11^{\prime \prime}$ West). Thirty-three sows (commercial breeders Fertilis 20 from Généticporc company), weighing $232.1 \pm 23.4 \mathrm{~kg}$ on average (mean \pm residual standard deviation) at 74 days of gestation, were used in a completely randomized experimental design, with 11 replicates per treatment. The deliveries occurred, on average, after 115 days of gestation. Litters from each sow were standardized up to $24 \mathrm{~h}$ after birth to an average of $11.3 \pm 1.3$ piglets, with an average weight of $1.4 \pm 0.1 \mathrm{~kg}$, and standardizations were performed using animals of the same treatment. During the gestation period, the environmental temperature ranged between $17.5 \pm 2.7^{\circ} \mathrm{C}$ and $24.8 \pm 3.4^{\circ} \mathrm{C}$, and during lactation, it ranged between $18.5 \pm 2.7^{\circ} \mathrm{C}$ and $23.1 \pm 2.9^{\circ} \mathrm{C}$. The sows were transferred from the gestation room to the maternity room after 107 days of gestation. All sows received the same diet up to 73 days of gestation, with $13.2 \mathrm{MJ} \mathrm{kg}^{-1}$ of digestible energy (DE), $148 \mathrm{~g} \mathrm{~kg}^{-1}$ of crude protein (CP), $52 \mathrm{~g} \mathrm{~kg}^{-1}$ of ash, and $43 \mathrm{~g} \mathrm{~kg}^{-1}$ of crude fiber (CF). Rations were given in one meal per day at $08.00 \mathrm{~h}$ in the following quantities: $2 \mathrm{~kg}$ day $^{-1}$ from 0 to 7 days and $2.4 \mathrm{~kg} \mathrm{day}^{-1}$ from 8 to 73 days of gestation.

From 74 to 114 days of gestation, sows were subjected to one of the dietary treatments (Table 1). Rations were given in one meal per day at $08.00 \mathrm{~h}$. Diets during gestation were formulated to meet the minimum requirements of daily intake of digestible amino acids, total nitrogen, and energy suggested by NRC (2012). The daily ration intake (Table 1) was adjusted based on the amounts of energy and lysine in the diets, so that sows would consume the same quantity of nutrients per day. To increase the amount of fiber in the diet, rice grain and soybean meal were partially substituted for defatted rice bran (DRB) and soybean hulls (SH). Lactation diet was also formulated in accordance with NRC (2012). In this phase, ration leftovers were collected to determine feed intake of individual sows. Piglets did not receive any supplementary food during the entire lactation period. Water was available ad libitum for sows and piglets throughout the experimental period.
The chemical composition of the diets was determined using the techniques described by AOAC (1990), except fiber (total, insoluble, and soluble), which was determined according to the enzymatic method described by Lee et al. (1992) using the enzymes alpha-amylase, glucoamylase, and protease, at $240 \mathrm{KNU}-\mathrm{T} / \mathrm{g}, 300 \mathrm{AGU} / \mathrm{mL}$, and $2.4 \mathrm{AU}-\mathrm{A} / \mathrm{g}$, respectively.

From 74 days of gestation, $0.35 \%$ of the indicator chromium oxide $\left(\mathrm{Cr}_{2} \mathrm{O}_{3}\right)$ was included in all the diets, and a partial collection of feces was performed daily from 82 to 87 days of gestation. Feces were analyzed to measure the levels of chromium oxide, ash, CP, ether extract (EE), neutral detergent fiber (NDF), gross energy (GE), and dry matter (DM). To determine the apparent total

Table 1 - Ingredients, chemical composition, and daily intake of gestation and lactation diets of sows

\begin{tabular}{|c|c|c|c|c|}
\hline \multirow[t]{2}{*}{ Item } & \multicolumn{3}{|c|}{$\begin{array}{l}\text { Total dietary fiber } \\
\text { level }\left(\mathrm{g} \mathrm{kg}^{-1}\right)^{1}\end{array}$} & \multirow[t]{2}{*}{ Lactation } \\
\hline & 156 & 223 & 282 & \\
\hline \multicolumn{5}{|l|}{ Ingredient $\left(\mathrm{g} \mathrm{kg}^{-1}\right)$} \\
\hline Defatted rice bran & 320 & 348 & 376 & 100 \\
\hline Rice grain & 570 & 442 & 314 & 611 \\
\hline Blood and bone meal & 40 & 40 & 40 & 45 \\
\hline Soybean meal & 42 & 21 & - & 216 \\
\hline Soybean hulls & - & 122 & 244 & - \\
\hline Limestone & 12.9 & 11.7 & 10.5 & 5.1 \\
\hline Salt & 2.2 & 2.3 & 2.4 & 3.55 \\
\hline Rice oil & 10 & 10 & 10 & 15 \\
\hline Vitamin and mineral premix ${ }^{2}$ & 2.74 & 2.74 & 2.74 & 3.61 \\
\hline Copper sulfate & 0.24 & 0.24 & 0.24 & 0.2 \\
\hline \multicolumn{5}{|l|}{ Analyzed composition $\left(\mathrm{g} \mathrm{kg}^{-1}\right)^{3}$} \\
\hline Crude protein & 156 & 139 & 129 & 202 \\
\hline Ashes & 66 & 81 & 96 & 63 \\
\hline Ether extract & 12.8 & 20.6 & 22.8 & 7.6 \\
\hline Crude fiber & 33 & 70 & 101 & 21 \\
\hline Neutral detergent fiber & 135 & 196 & 261 & - \\
\hline Acid detergent fiber & 40 & 102 & 118 & - \\
\hline Non-fibrous carbohydrates ${ }^{4}$ & 631 & 563 & 492 & - \\
\hline Insoluble food fiber & 106 & 169 & 207 & - \\
\hline Soluble food fiber & 50 & 54 & 75 & - \\
\hline Total dietary fiber & 156 & 223 & 282 & - \\
\hline Dry matter & 862 & 883 & 877 & 848 \\
\hline Gross energy $\left(\mathrm{MJ} \mathrm{kg}^{-1}\right)$ & 14.36 & 15.06 & 15.47 & 16.27 \\
\hline Digestible energy $\left(\mathrm{MJ} \mathrm{kg}^{-1}\right)$ & 12.54 & 12.24 & 11.92 & 14.4 \\
\hline \multicolumn{5}{|l|}{ Daily ration intake $(\mathrm{kg})$} \\
\hline 74 to 90 days of gestation & 2.10 & 2.21 & 2.40 & - \\
\hline 91 to 111 days of gestation & 2.47 & 2.65 & 2.85 & - \\
\hline 112 days of gestation & 1.70 & 1.82 & 1.96 & - \\
\hline 113 days of gestation & 1.00 & 1.07 & 1.15 & - \\
\hline Day of birth & 0.500 & 0.540 & 0.580 & - \\
\hline Lactation period & - & - & - & No restriction \\
\hline \multicolumn{5}{|c|}{$\begin{array}{l}{ }^{1} \text { Amounts of total dietary fiber level in gestation diets. } \\
2 \text { Guaranteed levels: vitamin A, 4,750,000 IU/kg; vitamin D3, 950,000 IU/kg; } \\
\text { vitamin E, } 17,500 \mathrm{IU} / \mathrm{kg} \text {; vitamin } \mathrm{K} 3,550 \mathrm{mg} / \mathrm{kg} \text {; vitamin B1, } 1,000 \mathrm{mg} / \mathrm{kg} \text {; } \\
\text { vitamin B2, 3,188 mg/kg; vitamin B6, 1,590.50 mg/kg; vitamin B12, } 9,000 \mathrm{mcg} / \mathrm{kg} \text {; } \\
\text { niacin, } 14,068 \mathrm{mg} / \mathrm{kg} \text {; pantothenic acid, } 8500 \mathrm{mg} / \mathrm{kg} \text {; folic acid, } 700 \mathrm{mg} / \mathrm{kg} \text {; } \\
\text { biotin, } 300 \mathrm{mg} / \mathrm{kg} \text {; choline chloride, } 104.14 \mathrm{~g} / \mathrm{kg} \text { B.H.T, } 250 \mathrm{mg} / \mathrm{kg} ; \text { calcium, } \\
60 \mathrm{~g} / \mathrm{kg} \text {; manganese, } 45 \mathrm{~g} / \mathrm{kg} \text {; zinc, } 170 \mathrm{~g} / \mathrm{kg} \text {; iron, } 80 \mathrm{~g} / \mathrm{kg} \text {; copper, } 12 \mathrm{~g} / \mathrm{kg} \text {; } \\
\text { iodine, } 750 \mathrm{mg} / \mathrm{kg} \text {; selenium, } 300 \mathrm{mg} / \mathrm{kg} \text {. } \\
{ }^{3} \text { As fed. }\end{array}$} \\
\hline
\end{tabular}


tract digestibility (ATTD) of the nutrients, the following equation, described by Sun et al. (2014), was used: ATTD $(\%)=100-\{100 \times[(\%$ of the indicator in the diet $/ \%$ of the indicator in the feces $) \times(\%$ of the nutrient in the feces $/ \%$ of the nutrient in the diet)]\}.

To determine the level of non-fibrous carbohydrates (NFC) in feed and feces, the following equation described by Weiss (1999) was used: NFC (\%) = $100-\mathrm{CP}(\%)-\mathrm{EE}$ $(\%)$ - NDF (\%) - Ash (\%). The GE of feed and feces was determined with a bomb calorimeter. The DE of the feed, during gestation and lactation, was determined using a software that calculated the digestible fraction from the GE and the nutrients contained in the diets (EvaPig, 2014).

Sows were weighed at 107 days of gestation and at days $4,11,18$, and 25 of lactation. The number and weight of all piglets was assessed at birth including live-born, stillborn, and mummified fetuses. Following standardization, the average daily weight gain (ADWG) of piglets and litters was calculated for the four periods. The total number of births is the sum of live-born, stillborn, and mummified piglets. The regression equation described by Noblet and Etienne (1989) was used to estimate milk production, based on the weight gain of the litter: milk production ( $\mathrm{g} /$ day) $=2.50 \times$ daily weight gain of the litter $(\mathrm{g} /$ day $)+80.2 \times$ litter weight after initial standardization $(\mathrm{kg})+7$. Milk production was estimated over four periods: from the day of standardization of the litter to day 4, days 5 to 11, days 12 to 18 , and days 19 to 25 . The piglets were weaned at 25 days of age.

To determine the interval between weaning and estrus manifestation, a boar was introduced into the pen containing the sows every morning and afternoon. Females that showed a positive behavior of tolerance to the backpressure test, performed by a person in the presence of the boar, were considered to be in estrus.

Blood was collected at 105 and 112 days of gestation and at 4, 11, 18, and 25 days of lactation. Collections were always performed in the afternoon, starting at $14.00 \mathrm{~h}$, using jugular venipuncture with a $100 \times 10 \mathrm{~mm}$ needle. Samples were collected using 50-mL Falcon tubes and a 4-mL tube of sodium fluoride to prevent glucose degradation. After collection, the blood samples were kept cool using a thermal box, and after $2 \mathrm{~h}$, the samples were centrifuged for $15 \mathrm{~min}$ at 3,000 rotations per minute. After centrifugation, $13.5-\mathrm{mL}$ aliquots of serum were divided among 1.5-mL microcentrifuge tubes using an automatic pipette. Concentrations of the following metabolites or hormones were measured: non-esterified fatty acids (NEFA), insulin, glucose, leptin, cholesterol, total protein, urea, and albumin. Samples were assayed for leptin and insulin levels immediately. Blood samples were frozen before measuring all the other variables.

The level of serum leptin was determined using an ELISA kit (dbc - Diagnostic Biochem Canada Inc) and the level of serum insulin using an electrochemiluminescence kit (Roche Diagnostics). The NEFA was determined using the Randox commercial kit, and all the other analyses were performed using Bioclin commercial kits. We used the following Bioclin kits: Glucose Monoreagent, K082; Cholesterol Monoreagent, K083; Total Protein Monoreagent, K031; Urea Enzyme, K047; Creatinine, K016; Albumine Monoreagent, K040; Phosphorus, K020; Calcium, K007; and Magnesium, K027. Analyses were conducted using a semi-automated biochemical analysis apparatus (Mindray, model BA-88A). The analyses were performed in duplicate, and the intra-assay coefficient of variation values were $3.8 \%$ for glucose, $3.9 \%$ for protein, $5.1 \%$ for albumin, $3.3 \%$ for creatinine, $4.7 \%$ for urea, $3.7 \%$ for cholesterol, and $4.1 \%$ for NEFA. Globulin values were calculated from the difference between the serum values of total protein and albumin.

Data were analyzed using the MIXED procedure of SAS software (Statistical Analysis System, version 9.4), and LSmeans were compared using Fisher's (LSD) test. Fixed effect of fiber level was included in all the models of analysis. When the variables were repeatedly measured (metabolites and hormones, milk production, feed intake during lactation, ADWG of piglets, and litter weight), they were analyzed as repeated measures, and the day of evaluation and its interaction with the fiber level were also included in the models as fixed effects. Linear and quadratic effects of fiber level were also investigated. Some covariates were tested with all variables, but only those that were significant at the $5 \%$ probability level were retained in the models. The weight of sows at 74 days gestation was used as a covariate for sow weight at 107 days of gestation and for serum concentrations of protein and globulin. The parity order of the sows was used as a covariate for weight variation during gestation ( $\mathrm{kg}$ and \%), milk production, sow weight, and serum levels of protein, albumin, and globulin during lactation. The number of piglets was used as a covariate for the total weight and ADWG of the litters, and the weight of piglets at standardization was used as a covariate for the weight of the piglets during nursing. The concentrations of NEFA and numbers and percentages of stillborn piglets and mummified fetuses were subjected to non-parametric analysis, and treatments or days of sampling were compared using the Kruskal-Wallis test. 


\section{Results}

The ATTD of DM, GE, CP, NFC, organic matter, and $\mathrm{DE}$ significantly decreased $(\mathrm{P}<0.05)$ with a higher TDF level in the diet (Table 2). The ATTD of EE was not affected by the TDF level. The lowest ATTD of the NDF was observed in the treatment with $223 \mathrm{~g} \mathrm{~kg}^{-1}$ of TDF. It can be observed that formulated DE (Table 1) was lower than DE obtained in the experiment (Table 2). This difference might be explained because the defatted rice bran used in the diets had a higher energy than the value defined in NRC (2012).

Variation of TDF in the diets did not affect $(\mathrm{P}>0.05)$ the weight or weight variation of sows between 74 and 107 days of gestation (Table 3). There were no differences in the number of total born, live-born, and mummified fetuses with increasing levels of dietary fiber $(\mathrm{P}>0.05)$. The weight of litters and mean birth weight of piglets were not affected by the level of TDF in the gestation diet $(\mathrm{P}>0.05)$ (Table 3).

There was an increase (quadratic $\mathrm{P}<0.05$ ) in the concentration of protein and globulin, while cholesterol showed a linear increase with the increase in TDF (Table 4). Serum concentrations of albumin, urea, glucose, leptin, and insulin were not affected $(\mathrm{P}>0.05)$ by the TDF in the diet, but were, in some cases, affected by the day of sampling $(\mathrm{P}<0.05)$ (Table 4). The concentrations of NEFA were not affected by the level of TDF in late gestation and at days 18 and 25 of lactation (Figure 1). The concentration of NEFA decreased at 112 days of gestation in sows fed the $282 \mathrm{~g} \mathrm{~kg}^{-1}$ diet, but significantly at the third week in sows fed the $156 \mathrm{~g} \mathrm{~kg}^{-1}$ TDF during lactation and from the second to fourth weeks in sows fed the $223 \mathrm{~g} \mathrm{~kg}^{-1} \mathrm{TDF}$ diet (Figure 1).

The other blood metabolites and hormones analyzed during lactation (Table 5) were not affected $(\mathrm{P}>0.05)$ by the TDF treatments, but were affected by the day of sampling $(\mathrm{P}<0.05)$ in almost all cases.

The weight of sows at weaning (overall $240.3 \pm 23.1 \mathrm{~kg}$ ), change of weight $(3.6,2.0$, and $-5.4 \mathrm{~kg})$, and the percentage of weight change $(1.7,1.3$, and $-2.2 \%)$ during lactation were not influenced $(\mathrm{P}>0.05)$ by the TDF level of diets $\left(156 \mathrm{~g} \mathrm{~kg}^{-1}\right.$, $223 \mathrm{~g} \mathrm{~kg}^{-1}$, and $282 \mathrm{~g} \mathrm{~kg}^{-1}$, respectively). The weaning-toestrus interval was $4.6 \pm 1.4$ days, with no difference $(\mathrm{P}>0.05)$ among the TDF levels. The amount of TDF in gestation diet

Table 2 - Effect of the amount of total dietary fiber in the diet of sows (74 to 114 days of gestation) on the apparent digestibility coefficients $\left(\mathrm{g} \mathrm{kg}^{-1}\right)$ and digestible energy (LSmeans)

\begin{tabular}{|c|c|c|c|c|c|c|c|}
\hline \multirow{2}{*}{ Variable } & \multicolumn{3}{|c|}{ Total dietary fiber level $\left(\mathrm{g} \mathrm{kg}^{-1}\right)$} & \multirow{2}{*}{ SEM } & \multicolumn{3}{|c|}{ P-value } \\
\hline & 156 & 223 & 282 & & Diets & $\mathrm{L}$ & Q \\
\hline Dry matter & $859 \mathrm{a}$ & $732 b$ & $684 \mathrm{c}$ & 4.95 & $<0.0001$ & $<0.0001$ & $<0.0001$ \\
\hline Gross energy & $887 \mathrm{a}$ & $782 b$ & $725 \mathrm{c}$ & 4.95 & $<0.0001$ & $<0.0001$ & 0.0003 \\
\hline Crude protein & $890 \mathrm{a}$ & $742 b$ & $635 c$ & 8.15 & $<0.0001$ & $<0.0001$ & 0.05 \\
\hline Ether extract & 630 & 648 & 655 & 39.56 & 0.90 & 0.66 & 0.92 \\
\hline Neutral detergent fiber & $694 a$ & $599 \mathrm{c}$ & $636 b$ & 58.00 & $<0.0001$ & 0.003 & $<0.0001$ \\
\hline Non-fibrous carbohydrates & $978 \mathrm{a}$ & $949 b$ & $917 \mathrm{c}$ & 55.32 & $<0.0001$ & $<0.0001$ & 0.91 \\
\hline Organic matter & $907 \mathrm{a}$ & $813 b$ & $763 \mathrm{c}$ & 41.85 & $<0.0001$ & $<0.0001$ & 0.0001 \\
\hline Digestible energy $\left(\mathrm{MJ} \mathrm{kg}^{-1}\right)$ & $14.8 \mathrm{a}$ & $13.3 b$ & $12.8 \mathrm{c}$ & 0.09 & $<0.0001$ & $<0.0001$ & 0.0002 \\
\hline
\end{tabular}

LSmeans - least square means; SEM - standard error of mean; L and Q - linear and quadratic response, respectively, for the fiber level.

Values in the row with different letters differ significantly at $\mathrm{P}<0.05$, after analysis of variance and comparison using the LSD test.

Table 3 - Effect of the amount of total dietary fiber in the diet of sows (74 to 114 days of gestation) on body weight and weight variation of sows during gestation and performance of the piglets at birth (LSmeans)

\begin{tabular}{|c|c|c|c|c|c|c|c|}
\hline \multirow{2}{*}{ Variable } & \multicolumn{3}{|c|}{ Total dietary fiber level $\left(\mathrm{g} \mathrm{kg}^{-1}\right)$} & \multirow{2}{*}{ SEM } & \multicolumn{3}{|c|}{ P-value } \\
\hline & 156 & 223 & 282 & & Diets & $\mathrm{L}$ & Q \\
\hline \multicolumn{8}{|l|}{ Sows } \\
\hline Weight at 107 days $(\mathrm{kg})$ & 244.2 & 245.7 & 248.0 & 7.14 & 0.49 & 0.24 & 0.88 \\
\hline Weight gain 74-107 days (kg) & 12.4 & 13.5 & 15.8 & 2.05 & 0.50 & 0.25 & 0.81 \\
\hline Weight gain 74-107 days (\%) & 5.5 & 5.8 & 7.0 & 0.87 & 0.43 & 0.22 & 0.68 \\
\hline \multicolumn{8}{|l|}{ Piglets } \\
\hline Total born & 13.7 & 13.2 & 12.5 & 1.43 & 0.82 & 0.54 & 0.94 \\
\hline Live-born & 13.0 & 12.8 & 12.0 & 1.30 & 0.84 & 0.58 & 0.84 \\
\hline Stillborn $^{1}$ & 0.6 & 0.2 & 0.2 & 0.25 & 0.51 & - & - \\
\hline Stillborn $(\%)^{1}$ & 4.2 & 1.0 & 1.1 & 1.38 & 0.42 & - & - \\
\hline Mummified $^{1}$ & 0.1 & 0.2 & 0.3 & 0.13 & 0.48 & - & - \\
\hline Mummified (\%) ${ }^{1}$ & 0.5 & 1.5 & 2.0 & 0.88 & 0.46 & - & - \\
\hline Piglet weight (kg) & 1.37 & 1.41 & 1.44 & 0.09 & 0.87 & 0.59 & 0.98 \\
\hline Litter weight (kg) & 17.5 & 17.2 & 16.1 & 1.26 & 0.68 & 0.41 & 0.78 \\
\hline
\end{tabular}

LSmeans - least square means; L and Q - linear and quadratic response, respectively, for the fiber level; SEM - standard error of mean.

${ }^{1}$ Non-parametric analysis and diets compared using the Kruskal-Wallis test. 
did not affect $(\mathrm{P}>0.05)$ the average daily feed intake of sows and the weight of the litter (Table 6). The ADWG of the litter and piglets showed a linear increase $(\mathrm{P}<0.05)$ with the increase in the TDF of the diet (Table 6). The significant interaction $(\mathrm{P}<0.05)$ between the treatment and day of evaluation was noted on the weight of piglets and milk production of sows (Figure 2). At 11 and 18 days of lactation, the piglets born from sows that received diets

Table 4 - Effect of the amount of total dietary fiber in the diet of sows (74 to 114 days of gestation) on blood and hormonal metabolites at 105 and 112 days of gestation (LSmeans)

\begin{tabular}{|c|c|c|c|c|c|c|c|c|c|c|c|}
\hline \multirow{2}{*}{ Variable } & \multicolumn{3}{|c|}{ Total dietary fiber level $\left(\mathrm{g} \mathrm{kg}^{-1}\right)$} & \multirow{2}{*}{ SEM } & \multicolumn{2}{|c|}{ Day of gestation } & \multirow{2}{*}{ SEM } & \multicolumn{4}{|c|}{ P-value } \\
\hline & 156 & 223 & 282 & & 105 & 112 & & Diets & Day & $\mathrm{L}$ & Q \\
\hline Protein $\left(\mathrm{g} \mathrm{L}^{-1}\right)$ & $61.1 \mathrm{~b}$ & $64.0 \mathrm{a}$ & $60.1 \mathrm{~b}$ & 1.01 & 62.1 & 61.5 & 0.72 & 0.03 & 0.34 & 0.48 & 0.009 \\
\hline Albumin $\left(\mathrm{g} \mathrm{L}^{-1}\right)$ & 31.1 & 31.7 & 33.2 & 0.73 & $31.2 b$ & $32.8 \mathrm{a}$ & 0.55 & 0.12 & 0.03 & 0.05 & 0.63 \\
\hline Globulin $\left(\mathrm{g} \mathrm{L}^{-1}\right)$ & $30.0 \mathrm{ab}$ & $32.3 \mathrm{a}$ & $26.9 b$ & 1.34 & $30.8 \mathrm{a}$ & $28.7 b$ & 0.84 & 0.03 & 0.003 & 0.11 & 0.03 \\
\hline Urea $\left(\mathrm{mmol} \mathrm{L}^{-1}\right)$ & 4.5 & 4.6 & 4.5 & 0.12 & 4.4 & 4.7 & 0.10 & 0.69 & 0.07 & 0.82 & 0.41 \\
\hline Glucose $\left(\mathrm{mmol} \mathrm{L}^{-1}\right)$ & 3.9 & 4.1 & 4.0 & 0.12 & 3.9 & 4.1 & 0.11 & 0.70 & 0.17 & 0.79 & 0.42 \\
\hline Cholesterol $\left(\mathrm{mmol} \mathrm{L}^{-1}\right)$ & $1.6 b$ & $1.7 \mathrm{~b}$ & $1.9 \mathrm{a}$ & 0.07 & 1.7 & 1.7 & 0.05 & 0.01 & 0.16 & 0.005 & 0.57 \\
\hline Leptin (ng mL $\left.\mathrm{mL}^{-1}\right)$ & 1.0 & 0.8 & 1.0 & 0.10 & $1.1 \mathrm{a}$ & $0.7 b$ & 0.09 & 0.46 & 0.001 & 0.78 & 0.23 \\
\hline Insulin $\left(\mu \mathrm{U} \mathrm{mL}^{-1}\right)$ & 0.7 & 0.7 & 0.5 & 0.11 & $0.5 b$ & $0.8 \mathrm{a}$ & 0.13 & 0.34 & 0.01 & 0.22 & 0.44 \\
\hline
\end{tabular}

LSmeans - least square means; SEM - standard error of mean; L and Q - linear and quadratic response, respectively, for the fiber level.

Values in the row, within fiber level of day, with different letters differ significantly at $\mathrm{P}<0.05$, after analysis of variance and comparison using the LSD test.

The interaction between fiber level and day of evaluation was not significant $(\mathrm{P}>0.05)$.
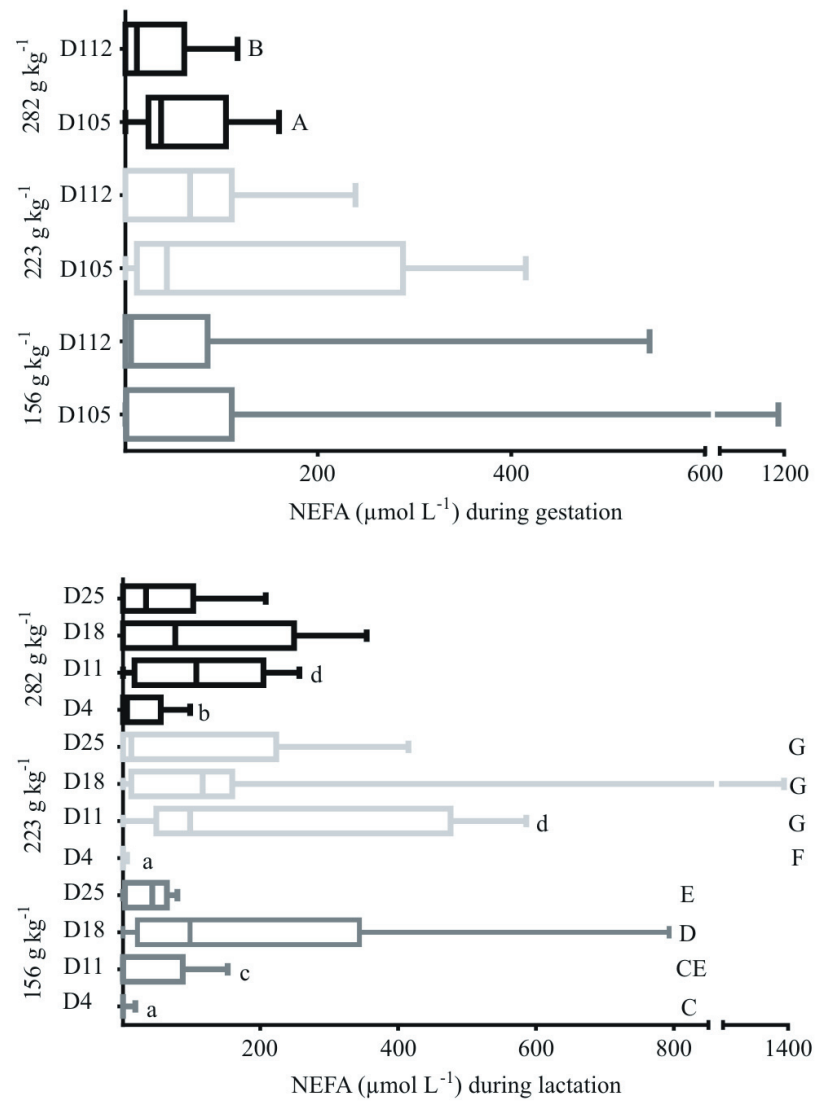

NEFA - non-esterified fatty acids.

From the left to the right, the minimum, $25 \%$ percentile, median, $75 \%$ percentile, and maximum values are represented in each box.

Data were subjected to non-parametric analysis, and comparisons were performed using the Kruskal-Wallis test.

a-b and c-d - Effect of diet on days 4 and 11, respectively $(\mathrm{P}<0.05)$.

$\mathrm{A}-\mathrm{B}, \mathrm{C}-\mathrm{E}$, and F-G - Effect of sampling day within 282,156 , and 223 and $\mathrm{g} \mathrm{kg}^{-1}$ diets, respectively $(\mathrm{P}<0.05)$.

Figure 1 - Concentrations of NEFA in late gestation (days 105 and 112) and during lactation (days 4, 11, 18, and 25) of sows fed gestation diets containing different levels of total dietary fiber $\left(156,223\right.$, or $\left.282 \mathrm{~g} \mathrm{~kg}^{-1}\right)$.
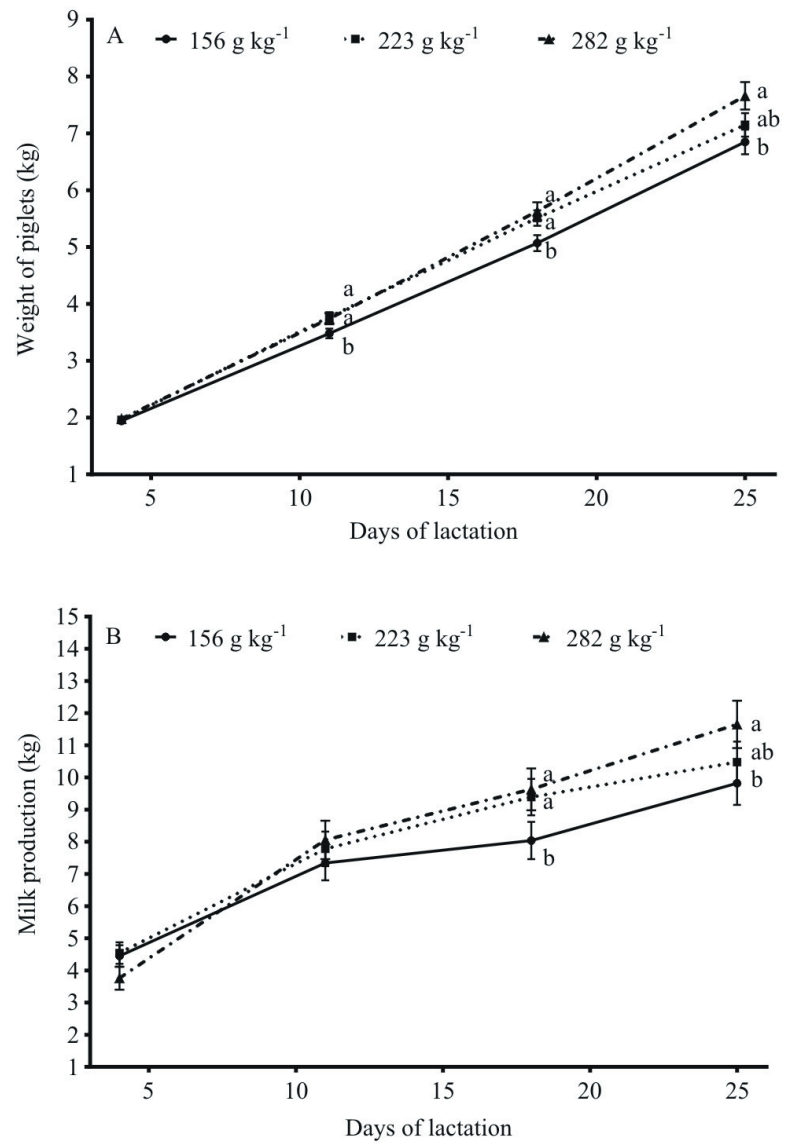

There was a treatment $\times$ day interaction $(\mathrm{P}<0.05)$ for both variables.

Lowercase letters, in the vertical, indicate differences (Panel A; $\mathrm{P}<0.05$ ) or tendency for difference (Panel $\mathrm{B} ; \mathrm{P}<0.10)$ between the treatments on different days $(\mathrm{P}<0.05)$.

Figure 2 - Average weight of piglets (A) and milk production of sows (B) according to the amount of total dietary fiber in the diet of sows during gestation $(156,223$, and $\left.282 \mathrm{~g} \mathrm{~kg}^{-1}\right)$. 
with $223 \mathrm{~g} \mathrm{~kg}^{-1}$ and $282 \mathrm{~g} \mathrm{~kg}^{-1}$ of TDF during gestation showed an average weight greater $(\mathrm{P}<0.05)$ than those born from sows fed $156 \mathrm{~g} \mathrm{~kg}^{-1}$ of TDF. At 25 days, the piglets of sows that received the diet with $282 \mathrm{~g} \mathrm{~kg}^{-1}$ of TDF still remained heavier $(\mathrm{P}<0.05)$ than those from sows receiving $156 \mathrm{~g} \mathrm{~kg}^{-1}$ of TDF (Figure 2A). At 18 days of lactation, sows fed $282 \mathrm{~g} \mathrm{~kg}^{-1}$ and $223 \mathrm{~g} \mathrm{~kg}^{-1}$ TDF tended $(\mathrm{P}<0.10)$ to have higher milk production than sows fed $156 \mathrm{~g} \mathrm{~kg}^{-1} \mathrm{TDF}$ (Figure 2). The sows fed $282 \mathrm{~g} \mathrm{~kg}^{-1}$ TDF diet tended $(\mathrm{P}=0.07)$ to produce more milk than those fed $156 \mathrm{~g} \mathrm{~kg}^{-1} \mathrm{TDF}$ at 25 days of lactation (Figure 2B).

\section{Discussion}

This study aimed to meet the nutritional requirements of sows, despite the variation in diet composition. The daily energy intake from 74 to 90 days of gestation was 26.8, 26.0, and $26.9 \mathrm{MJ} \mathrm{kg}^{-1}$ of DE and 327, 306, and $308 \mathrm{~g}$ of $\mathrm{CP}$, for the 156,223 , and $282 \mathrm{~g} \mathrm{~kg}^{-1}$ TDF treatments, respectively. From 91 to 111 days of gestation, intake was 31.5, 31.2, and $32.0 \mathrm{MJ} \mathrm{kg}^{-1}$ of DE and 385,367 , and $366 \mathrm{~g}$ of $\mathrm{CP}$. Although many positive results have been observed with up to $110 \mathrm{~g} \mathrm{~kg}^{-1} \mathrm{CF}$ added to the feed (Quesnel et al., 2009; Veum et al., 2009), amounts of CF over $130 \mathrm{~g} \mathrm{~kg}^{-1}$ may reduce sow weight gain during gestation and the weight of piglets at birth (Gentilini et al., 2004). This occurs especially if the voluntary feed intake of sows is affected, as observed by van der Peet-Schwering et al. (2003) and Danielsen and Vestergaard (2001) in studies with diets containing $300 \mathrm{~g} \mathrm{~kg}^{-1}$ of non-starch polysaccharides (NSP) and $446 \mathrm{~g} \mathrm{~kg}^{-1}$ of total dietary fiber, respectively. Gentilini et al. (2004) evaluated a diet containing $350 \mathrm{~g} \mathrm{~kg}^{-1}$ soybean hulls (131 $\mathrm{g} \mathrm{kg}^{-1}$ of $\mathrm{CF}$ in the diet), and even though the energy intake was not affected by $\mathrm{CF}$ level, the females that consumed less fiber (45 $\mathrm{g} \mathrm{kg}^{-1}$ of CF) weighed more at 110 days of gestation. In other studies (Holt et al., 2006; Darroch et al., 2008), sows also gained less weight during gestation when they received high-fiber diets. The reduced weight gain can be attributed to the increased rate of feed passage through the gastrointestinal tract (Jorgensen et al., 1996; Lattimer and Haub, 2010), which lowers the ATTD of nutrients and energy from the diet. In the present study, gestating sows consumed all the ration offered, showing that $282 \mathrm{~g} \mathrm{~kg}^{-1}$ of TDF, corresponding to $101 \mathrm{~g} \mathrm{~kg}^{-1} \mathrm{CF}$ (376 g kg-1 of defatted rice bran and $244 \mathrm{~g} \mathrm{~kg}^{-1}$ of soybean hulls) did not limit the voluntary intake and, despite lowering the ATTD

Table 5 - Effect of the amount of total dietary fiber in the diet of sows ( 74 to 114 days of gestation) on blood and hormonal metabolites at $4,11,18$, and 25 days of lactation (LSmeans)

\begin{tabular}{|c|c|c|c|c|c|c|c|c|c|c|c|c|c|}
\hline \multirow{2}{*}{ Variable } & \multicolumn{3}{|c|}{ Total dietary fiber level $\left(\mathrm{g} \mathrm{kg}^{-1}\right)$} & \multirow{2}{*}{ SEM } & \multicolumn{4}{|c|}{ Day of lactation } & \multirow{2}{*}{ SEM } & \multicolumn{4}{|c|}{ P-value } \\
\hline & 156 & 223 & 282 & & 4 & 11 & 18 & 25 & & Diets & Day & $\mathrm{L}$ & Q \\
\hline Protein $\left(\mathrm{g} \mathrm{L}^{-1}\right)$ & 65.2 & 66.0 & 63.9 & 1.12 & $63.5 b$ & $64.9 \mathrm{ab}$ & $65.6 \mathrm{a}$ & $66.2 \mathrm{a}$ & 0.88 & 0.38 & 0.05 & 0.41 & 0.24 \\
\hline Albumin $\left(\mathrm{g} \mathrm{L}^{-1}\right)$ & 29.8 & 29.9 & 29.0 & 0.81 & $31.1 \mathrm{a}$ & $28.4 b$ & $28.9 \mathrm{bc}$ & $29.9 \mathrm{ac}$ & 0.58 & 0.68 & $<0.0001$ & 0.46 & 0.59 \\
\hline Globulin $\left(\mathrm{g} \mathrm{L}^{-1}\right)$ & 35.4 & 36.1 & 34.7 & 1.51 & $32.4 \mathrm{~b}$ & $36.4 \mathrm{a}$ & $36.8 \mathrm{a}$ & $36.2 \mathrm{a}$ & 1.12 & 0.79 & $<0.0001$ & 0.74 & 0.54 \\
\hline Urea $\left(\mathrm{mmol} \mathrm{L}^{-1}\right)$ & 7.85 & 7.90 & 7.92 & 0.29 & $6.99 \mathrm{c}$ & $8.01 \mathrm{~b}$ & $8.07 \mathrm{ab}$ & $8.49 \mathrm{a}$ & 0.21 & 0.98 & $<0.0001$ & 0.86 & 0.96 \\
\hline Glucose $\left(\mathrm{mmol} \mathrm{L}^{-1}\right)$ & 4.66 & 4.60 & 4.57 & 0.14 & 4.54 & 4.55 & 4.70 & 4.64 & 0.14 & 0.88 & 0.75 & 0.65 & 0.86 \\
\hline Cholesterol (mmol L $\left.{ }^{-1}\right)$ & 2.19 & 2.19 & 2.20 & 0.08 & $2.14 b$ & $2.16 b$ & $2.08 \mathrm{~b}$ & $2.39 \mathrm{a}$ & 0.06 & 0.99 & $<0.0001$ & 0.97 & 0.92 \\
\hline Leptin (ng mL ${ }^{-1}$ ) & 1.23 & 1.27 & 1.04 & 0.14 & $1.14 \mathrm{a}$ & $1.23 \mathrm{a}$ & $1.65 \mathrm{a}$ & $0.70 b$ & 0.12 & 0.44 & $<0.0001$ & 0.30 & 0.39 \\
\hline Insulin $\left(\mu \mathrm{U} \mathrm{mL} \mathrm{mL}^{-1}\right)$ & 4.42 & 4.04 & 2.98 & 0.69 & 4.43 & 3.90 & 3.36 & 3.56 & 0.60 & 0.30 & 0.59 & 0.13 & 0.65 \\
\hline
\end{tabular}

LSmeans - least square means; SEM - standard error of mean; L and Q - linear and quadratic response, respectively, for the fiber level.

Values in the row, within fiber level of day, with different letters differ significantly at $\mathrm{P}<0.05$, after analysis of variance and comparison using the LSD test.

The interaction between fiber level and day of evaluation was not significant $(\mathrm{P}>0.05)$.

Table 6 - Effect of the amount of total dietary fiber in the diet of sows (74 to 114 days of gestation) on average daily feed intake (ADFI) of sows and performance of piglets during lactation (LSmeans)

\begin{tabular}{|c|c|c|c|c|c|c|c|c|c|c|c|c|c|}
\hline \multirow{2}{*}{ Variable } & \multicolumn{3}{|c|}{ Total dietary fiber level $\left(\mathrm{g} \mathrm{kg}^{-1}\right)$} & \multirow{2}{*}{ SEM } & \multicolumn{4}{|c|}{ Day of lactation } & \multirow{2}{*}{ SEM } & \multicolumn{4}{|c|}{ P-value } \\
\hline & 156 & 223 & 282 & & 4 & 11 & 18 & 25 & & Diets & Day & $\mathrm{L}$ & Q \\
\hline \multicolumn{14}{|l|}{ Sows } \\
\hline ADFI (kg) & 7.2 & 7.2 & 7.4 & 0.23 & $5.7 \mathrm{~d}$ & $7.3 \mathrm{c}$ & $7.8 \mathrm{~b}$ & $8.2 \mathrm{a}$ & 0.18 & 0.79 & $<0.0001$ & 0.52 & 0.78 \\
\hline \multicolumn{14}{|l|}{ Litter } \\
\hline Weight (kg) & 44.3 & 47.8 & 48.1 & 1.93 & $20.8 \mathrm{~d}$ & $38.2 \mathrm{c}$ & $55.1 \mathrm{~b}$ & $72.8 \mathrm{a}$ & 1.10 & 0.24 & $<0.0001$ & 0.14 & 0.45 \\
\hline ADWG (kg) & $1.9 \mathrm{~b}$ & $2.2 \mathrm{a}$ & $2.3 \mathrm{a}$ & 0.10 & $1.1 \mathrm{~b}$ & $2.4 \mathrm{a}$ & $2.4 \mathrm{a}$ & $2.6 \mathrm{a}$ & 0.09 & 0.03 & $<0.0001$ & 0.02 & 0.36 \\
\hline \multicolumn{14}{|l|}{ Piglets } \\
\hline ADWG (g) & $207 b$ & $217 \mathrm{ab}$ & $238 \mathrm{a}$ & 8.79 & $132 b$ & $243 a$ & $248 \mathrm{a}$ & $260 \mathrm{a}$ & 8.09 & 0.04 & $<0.0001$ & 0.02 & 0.61 \\
\hline
\end{tabular}

LSmeans - least square means; SEM - standard error of mean; L and Q - linear and quadratic response, respectively, for the fiber level; ADWG - average daily weight gain. Values in the row, within fiber level of day, with different letters differ significantly at $\mathrm{P}<0.05$, after analysis of variance and comparison using the LSD test.

The interaction between fiber level and day of evaluation was not significant $(\mathrm{P}>0.05)$. 
of nutrients and energy, did not affect the weight gain of gestating sows.

As the levels of dietary fiber increased, a corresponding decrease in DE and ATTD of DM, GE, CP, NFC, and OM was observed, agreeing with results of Le Gall et al. (2009). The greater amount of fiber in the diet leads to important physiological changes, such as an increased viscosity of the diet (NSP in wheat) (Kim et al., 2005), but insoluble fiber, on the other hand, reduces time for the passage of chyme (Jorgensen et al., 1996; Lattimer and Haub, 2010), which decreases the fermentation time in the large intestine (Wilfart et al., 2007).

The greater quantity of fiber in the gestation diet might indirectly increase the energy available to the fetuses (Lee and Close, 1987) by improving the welfare of females and reducing the stereotypical behaviors and physical movement of the sows (Ramonet et al., 1999; Gentilini et al., 2003), which would explain the higher weight of piglets at birth (Veum et al., 2009). However, this response was not observed in the present study (Table 2). Ramonet et al. (2000) suggested that the greater energy availability that results from the lower physical activity of the females is lost, as part of the energy is converted into heat by the fermentation of the fiber. Thus, the weight of the piglets may not be affected by the amounts of fiber in the diet of gestating sows. Similarly, the number of live-born and stillborn piglets was not affected by the diet treatments, which is in agreement with other studies in which higher quantities of fiber were provided only during gestation (Gentilini et al., 2004; Renteria-Flores et al., 2008; Quesnel et al., 2009). In contrast to these results, van der Peet-Schwering et al. (2003) observed an increase of 0.5 piglets at birth, for the first cycle, and 0.7 piglets at birth, for the second cycle, in females that consumed NSP-rich diets. However, the authors attributed this improvement to greater embryonic survival, given that the NSP-rich diets were provided before confinement for gestation.

Several factors can apparently influence hematologic metabolites (Klem et al., 2010) including the level of crude protein of diet (Toledo et al., 2014). However, as the daily intake of CP was similar, there is currently no obvious explanation for the increase in protein and globulins in the diet with $223 \mathrm{~g} \mathrm{~kg}^{-1}$ of TDF during gestation. In human species, serum cholesterol reduces with an increase in fiber consumption (Martensson et al., 2005), contrasting the increased cholesterol observed in sows that received diet with $282 \mathrm{~g} \mathrm{~kg}^{-1}$ of TDF. The experimental diets presented increasing levels of EE as the fiber increased, and the difference in fat intake may have influenced the cholesterol level.

A higher amount of fiber in the diet increases glucose (Quesnel et al., 2009) and insulin (Quesnel et al., 2009;
Loisel et al., 2013) levels in the blood of gestating sows. However, this variation was observed up to 60 and 75 min after feeding for glucose and insulin, respectively. Probably, the influence of fiber in slowing glucose absorption (Lattimer and Haub, 2010), hence altering blood insulin and glucose levels, was more noticeable soon after intake. In this study, blood samples were collected at $6 \mathrm{~h}$ after intake of the experimental rations, and no effect was observed on either glucose or insulin levels.

The increased concentrations of urea observed as lactation progressed, irrespective of the CF level of gestation diet, may be partly explained by the increased catabolism of endogenous proteins due to the higher demands for milk production (Quesnel et al., 2009). The NEFA concentration has been used as an indicator of the energy status and fat catabolism of sows (Rojkittikhun et al., 1993; Valros et al., 2003). Serum concentrations of NEFA were not affected by the level of CF in gestation diet, at 18 and 25 days of lactation, as reported in other studies (Quesnel et al., 2009; Loisel et al., 2013). Although a significant increase in concentrations of NEFA as the lactation progressed was not observed for all the diets in the present study, it is common for NEFA to increase around the third week of lactation (Valros et al., 2003; Quesnel et al., 2009), due to the higher mobilization of lipids from fatty tissue to fulfill the demand for milk production (Valros et al., 2003). Nevertheless, the concentration of NEFA not always increases as lactation progresses; it can be low at 14 days of lactation if sows have high fat reserves in late gestation or if they lose less weight during lactation (Hultén et al., 1993). Furthermore, the large variation in NEFA concentration observed between individuals, irrespective of the diet consumed, makes its interpretation difficult, as already pointed out by Verheyen et al. (2007), who considered that only major changes may have a significant influence on the health status of animals. Although litter weight gain has been positively affected by NEFA concentration (Valros et al., 2003), piglet growth is not always related to higher mobilization of body reserves because Quesnel et al. (2009) reported that sows fed highfiber diet mobilized similar body reserves and had similar NEFA concentrations to those fed the low-fiber diet, despite having piglets with increased growth rate.

Leptin is a hormone secreted by the adipose tissue and its release is negatively correlated with feed intake (Barb, 1999). Quesnel et al. (2009) verified that females that consumed a diet with more fiber presented a lower concentration of leptin in the blood at the end of gestation and greater ration intake during lactation. However, these responses were not observed in the present study. 
In the present study, weight gain during gestation and leptin levels were not affected by the TDF level of gestation diet, thus reducing the expectation that a higher feed intake would occur during lactation. Higher feed intake during lactation can increase the weight gain of piglets as it was already reported for sows fed high-fiber diets during gestation (Veum et al., 2009; Quesnel et al., 2009). In the present study, however, there was only a numerical difference in feed intake in favor of sows fed $282 \mathrm{~g} \mathrm{~kg}^{-1}$ compared with $156 \mathrm{~g} \mathrm{~kg}^{-1}$ TDF. Despite that, milk production tended to be higher in sows fed $282 \mathrm{~g} \mathrm{~kg}^{-1}$ TDF compared with those fed $156 \mathrm{~g} \mathrm{~kg}^{-1} \mathrm{TDF}$, at 18 and 25 days of lactation, probably explaining the improved growth performance of piglets from the sows fed the high-fiber diet. Darroch et al. (2008) and Gentilini et al. (2004) observed that females receiving diets with 200 and $350 \mathrm{~g} \mathrm{~kg}^{-1}$ of soybean hulls during gestation consumed 200 and $310 \mathrm{~g}$ more ration per day, respectively, during lactation. The increased feed intake during lactation could result from the increased extension and length of the gastrointestinal tract due to the high-fiber diet intake, as observed in young pigs (Jorgensen et al., 1996). Renteria-Flores et al. (2008) discussed the possibility that the higher feed intake during lactation elicited by soybean hulls could be related to the reduced energy intake and the lower weight gain during gestation. Also, high-fiber diets can reduce leptin levels before farrowing, which can be responsible for the increased feed intake during lactation (Quesnel et al., 2009).

\section{Conclusions}

Even with a reduction in the apparent total tract digestibility of nutrients and energy, the $282 \mathrm{~g} \mathrm{~kg}^{-1}$ of total dietary fiber diet may be used during gestation $\left(376 \mathrm{~g} \mathrm{~kg}^{-1}\right.$ of defatted rice bran and $244 \mathrm{~g} \mathrm{~kg}^{-1}$ of soybean hulls), as it does not impair the performance of sows during gestation and lactation or the birth weight of piglets. A greater total dietary fiber in the gestation diet improves the weight gain of piglets until weaning, even when there are no statistical differences in feed intake during lactation among sows fed different total dietary fiber levels during gestation.

\section{Acknowledgments}

We acknowledge Yargo Piggery of Itaqui - RS, for allowing this study to be carried out at the company; LNF Latino Americana (Novozymes), for donating enzymes; Bioclin Quibasa, for the donation of kits for biochemical analyses; and Universidade Federal do Pampa
(UNIPAMPA), for financial support (PROPPI - 01/2018) for publication of this article.

\section{References}

AOAC - Association of Official Analytical Chemists. 1990. Official methods of analysis. 15th ed. AOAC International, Arlington, VA.

Barb, C. R. 1999. The brain-pituitary-adipocyte axis: role of leptin in modulating neuroendocrine function. Journal of Animal Science $77: 1249-1257$

Danielsen, V. and Vestergaard, E. M. 2001. Dietary fibre for pregnant sows: effect on performance and behaviour. Animal Feed Science and Technology 90:71-80.

Darroch, C. S.; Dove, C. R.; Maxwell, C. V.; Johnson, Z. B. and Southern, L. L. 2008. A regional evaluation of the effect of fiber type in gestation diets on sow reproductive performance. Journal of Animal Science 86:1573-1578.

EvaPig. 2014. Calculator of energy, amino acid and phosphorus values of ingredients and diets for growing and adult pigs. Was created, designed and developed by INRA, AFZ and AJINOMOTO EUROLYSINE S.A.S. Version 1.3.1.7. Available at: $<$ http://www.evapig.com/x-home-en>. Accessed on: Sep. 15, 2015.

Gentilini, F. P.; Dallanora, D.; Bernardi, M. L.; Wentz, I. and Bortolozzo, F. P. 2003. Behaviour of pregnant gilts fed low or high fiber diets and maintained in crates or stalls. Arquivo Brasileiro de Medicina Veterinária e Zootecnia 55:599-605.

Gentilini, F. P.; Dallanora, D.; Peixoto, C. H.; Bernardi, M. L.; Wentz, I. and Bortolozzo, F. P. 2004. Productive perfomance of gilts fed gestation diets with low or high soybean hulls level. Ciência Rural $34: 1177-1183$

Holt, J. P.; Johnston, L. J.; Baidoo, S. K. and Shurson, G. C. 2006. Effects of a high-fiber diet and frequent feeding on behavior, reproductive performance, and nutrient digestibility in gestating sows. Journal of Animal Science 84:946-955.

Hultén, F.; Neil, M.; Einarsson, S. and Hakansson, J. 1993. Energy metabolism during late gestation and lactation in multiparous sows in relation to backfat thickness and the interval from weaning to first oestrus. Acta Veterinaria Scandinavica 34:9-20.

Jorgensen, H.; Zhao, X-Q. and Eggum, B. O. 1996. The influence of dietary fibre and environmental temperature on the development of the gastrointestinal tract, digestibility, degree of fermentation in the hind-gut and energy metabolism in pigs. British Journal of Nutrition 75:365-378.

Kim, J. C.; Simmins, P. H.; Mullan, B. P. and Pluske, J. R. 2005. The digestible energy value of wheat for pigs, with special reference to the post weaned animal. Animal Feed Science and Technology 122:257-287.

Klem, T. B.; Bleken, E.; Morberg, H.; Thoresen, S. I. and Framstad, T. 2010. Hematologic and biochemical reference intervals for Norwegian crossbreed grower pigs. Veterinary Clinical Pathology 39:221-226.

Lattimer, J. M. and Haub, M. D. 2010. Effects of dietary fiber and its components on metabolic health. Nutrients 2:1266-1289.

Le Gall, M.; Warpechowski, M.; Jaquelin-Peyraud, Y. and Noblet, J. 2009. Influence of dietary fiber level and pelleting on the digestibility of energy and nutrients in growing pigs and adult sows. Animal 3:352-359.

Lee, P. A. and Close, W. H. 1987. Bulky feeds for pigs: A consideration of some non-nutritional aspects. Livestock Production Science $16: 395-405$.

Lee, S. C.; Prosky, L. and Devries, J. W. 1992. Determination of total, soluble and insoluble dietary fiber in foods: enzymatic- 
gravimetric method, MES-TRIS buffer: collaborative study. Journal Association of Official Analytical Chemists 75:395-416.

Loisel, F.; Farmer. C.; Ramaekers, P. and Quesnel, H. 2013. Effects of high fiber intake during late pregnancy on sow physiology, colostrum production, and piglet performance. Journal of Animal Science 91:5269-5279.

Martensson, O.; Björklund, M.; Lambo, A. M.; Dueñas-Chasco, M.; Irastorza, A.; Holst, O.; Norin, E.; Welling, G.; Öste, R. and Önning, G. 2005. Fermented, ropy, oat-based products reduce cholesterol levels and stimulate the bifidobacteria flora in humans. Nutrition Research 25:429-442.

NRC - National Research Council. 2012. Nutrient requirements of swine. 11th ed. Committee on Nutrient Requirements of Swine, Board on Agriculture and Natural Resources, Division on Earth and Life Studies. Washington, D.C.

Noblet, J. and Etienne, M. 1989. Estimation of sow milk nutrient output. Journal of Animal Science 67:3352-3359.

Quesnel, H.; Meunier-Salaűn, M. C.; Hamard, A.; Guillemet, R.; Etienne, M.; Farmer, C.; Dourmad, J. Y. and Père, M. C. 2009. Dietary fiber for pregnant sows: influence on sow physiology and performance during lactation. Journal of Animal Science 87:532-543.

Ramonet, Y.; Meunier-Salaűn, M. C. and Dourmad, J. Y. 1999. Highfiber diets in pregnant sows: digestive utilisation and effects on the behavior of the animals. Journal of Animal Science 77:591-599.

Ramonet, Y.; van Milgen, J.; Dourmad J. Y.; Dubois, S.; MeunierSalaün, M. C. and Noblet, J. 2000. The effect of dietary fiber on energy utilization and partitioning of heat production over pregnancy in sows. British Journal of Nutrition 84:85-94.

Reese, D.; Prosch, A.; Travnicek, D. A. and Eskridge, K. M. 2008. Dietary fiber in sow gestation diets - an updated review. Available at: $<\mathrm{http}$ ///digitalcommons.unl.edu/cgi/viewcontent.cgi? article $=1044$ \&context=coopext_swine $>$. Accessed on: Jul. 21, 2014.

Renteria-Flores, J. A.; Johnston, L. J.; Shurson, G. C.; Moser, R. L. and Webel, S. K. 2008. Effect of soluble and insoluble dietary fiber on embryo survival and sow performance. Journal of Animal Science 86:2576-2584.

Rojkittikhun, T.; Einarsson, S.; Uvnäs-Moberg, K. and Edqvist, L. E. 1993. Body weight loss during lactation in relation to energy and protein metabolism in standard-fed primiparous sows. Journal of Veterinary Medicine 40:249-257.

Sun, H. Q.; Zhou, Y. F.; Tan, C. Q.; Zheng, L. F.; Peng, J. and Jiang, S. W. 2014. Effects of konjac flour inclusion in gestation diets on the nutrient digestibility, lactation feed intake and reproductive performance of sows. Animal 8:1089-1094.

Toledo, J. B.; Furlan, A. C.; Pozza, P. C.; Carraro, J.; Moresco, G.; Ferreira, S. L. and Gallego, A. G. 2014. Reduction of the crude protein content of diets supplemented with essential amino acids for piglets weighing 15 to 30 kilograms. Revista Brasileira de Zootecnia 43:301-309.

Valros, A.; Rundgren, M.; Spinka, M.; Saloniemi, H.; Rydhmer, L.; Hultén, F.; Uvnäs-Moberg, K.; Tománek, M.; Krejcí, P. and Algers, B. 2003. Metabolic state of the sow, nursing behavior and milk production. Livestock Production Science 79:155-167.

van der Peet-Schwering, C. M.; Kemp, B.; Binnendijk, G. P.; den Hartog, L. A.; Spoolder, H. A. and Vertegen, M. W. 2003. Performance of sows fed high levels of nonstarch polysaccharides during gestation and lactation over three parities. Journal of Animal Science 81:2247-2258.

Verheyen, A. J. M.; Dominiek, M. G. D.; Mateusen, B.; Deprez, P.; Janssens, G. P. J.; Lange, L. and Counotte, G. 2007. Serum biochemical reference values for gestating and lactating sows. The Veterinary Journal 174:92-98.

Veum, T. L.; Crenshaw, J. D.; Crenshaw, T. D.; Cromwell, G. L.; Easter, R. A.; Ewan, R. C.; Nelssen, J. L.; Miller, E. R.; Pettigrew, J. E. and Ellersieck, M. R. 2009. The addition of ground wheat straw as a fiber source in the gestation diet of sows and the effect on sow and litter performance for three successive parities. Journal of Animal Science 87:1003-1012.

Weiss, W. P. 1999. Energy prediction equations for ruminant feeds. p.176-185. In: Proceedings of the 61th Cornell Nutrition Conference for Feed Manufacturers. Cornell University, Ithaca.

Weldon, W. C.; Thuilin, A. J.; MacDougald, O. A.; Johnston, L. J.; Miller, E. R. and Tucker, H. A. 1991. Effects of increased dietary energy and protein during late gestation on mammary development in gilts. Journal of Animal Science 69:194-200.

Wilfart, A.; Montagne, L.; Simmins, H.; Noblet, J. and van Milgen, J. 2007. Digesta transit in different segments of the gastrointestinal tract of pigs as affected by insoluble fibre supplied by wheat bran. British Journal of Nutrition 98:54-62. 